\title{
Evaluation of Physiological Parameters of Broilers with Dorsal Cranial Myopathy
}

-Author(s)
Amaral PC'
Zimermann C"
Santos LR'
Noro M"I
Prá MD'
Pilotto F'
Rodrigues LB'
Dickel EL'
I Programa de Pós-Graduação em Bioexperi-
mentação, Faculdade de Agronomia e Me-
dicina Veterinária (FAMV), Universidade de
Passo Fundo (UPF)
" Curso de Medicina Veterinária, Universida-
de Federal de Santa Catarina (UFSC), Cam-
pus Curitibanos
II Curso de Medicina Veterinária, Campus
Uruguaiana, Universidade Federal do Pam-
pa, Uruguaiana
Iv Médico Veterinário, Iniciativa Privada

\section{-Mail Address}

Corresponding author e-mail address Pamela Cemin Amaral

Rua Morom - 2603 apto 302, Passo Fundo, RS, Brazil. 99010-035

Tel: $\quad$ (55 54) 99944-2099

Email: pamela_cemin@hotmail.com

\section{-Keywords}

Aspartate aminotransferase; complete blood count; creatine kinase; lactate; muscle injury.

\section{ABSTRACT}

There are several causes of carcass condemnation in poultry processing plants, including dorsal cranial myopathy (DCM), in which the anterior latissimus dorsi (ALD) muscle is affected. DCM etiology has not been elucidated yet, but this lesion impairs the visual quality of carcasses and causes economic losses due to downgrading and condemnation. The effects of this lesion on the systemic health of broilers are still unknown. In this context, the objective of this study was to evaluate muscle injury and systemic health indicators in broilers presenting or not DCM. The following parameters were evaluated: complete blood count $(C B C)$, total protein, albumin, globulin, cholesterol, lactate, and glucose serum levels, aspartate aminotransferase (AST) and creatine kinase (CK) serum activities, and breast muscle $\mathrm{pH}$. Blood samples were collected from 800 42-day-old broilers before feed withdrawal and transportation. In the processing plant, 28 carcasses presented DCM during inspection, and 28 carcasses with no DCM were used as controls. Blood biochemical parameters were not significantly different between broilers with DCM and the controls, except for AST and CK, which activities were higher in the DCM group than in the control group, suggesting that the DCM does not affect the systemic health of the broilers.

\section{INTRODUCTION}

Intensive genetic selection of broilers, aiming at marketing birds at increasingly younger ages, has led to physiological abnormalities, which may cause muscle tissue injuries, such as myopathies (Olivo \& Shimokomaki, 2002). The etiology of myopathies, which affect the visual quality of broiler carcasses, has not been elucidated yet (Zimermann et al., 2012).

The anterior latissimus dorsi (ALD) muscle of chickens may present a lesion known as dorsal cranial myopathy(DCM). The affected carcasses present yellowish color among the wings, subcutaneous edema, and an odorless gelatinous citrine-yellow fluid at the affected site. The injured ALD muscle presents hemorrhagic areas, increased density, pallor, adherences to adjacent muscles and, upon sectioning, the affected muscles are thicker than the unaffected ones (Zimermann, 2008). According to data obtained by the Brazilian Ministry of Agriculture (MAPA), DCM-compatible lesions were first observed in broiler processing inspection lines in 2002, and have since been reported in several processing plants across the country, particularly in the state of Rio Grande do Sul, in southern Brazil. This myopathy causes economic losses due to carcass downgrading and condemnations (Amaral, 2014).

The occurrence of DCM must be notified to the Department of Animal Product Inspection of the state of Rio Grande do Sul as of October, 2010, and, according to MAPA regulations (Brasil, 2010), broiler carcasses presenting DCM must be downgraded or condemned. 
Amaral PC, Zimermann C, Santos LR, Noro M, Prá MD, Pilotto F, Rodrigues LB, Dickel EL
Evaluation of Physiological Parameters of Broilers

with Dorsal Cranial Myopathy
In general, carcasses with DCM are trimmed, with the removal of the skin (often from the neck to the cloaca), of the affected and adjacent muscles, as well as of the humerus and of part of the thoracic muscles. Carcasses presenting extensive lesions that compromise their overall visual quality are condemned as a whole (Amaral, 2014).

DCM usually affects apparently healthy heavy broilers. A gradual increase in carcass downgrading and condemnations due to DCM has been detected, particularly in winter, when its incidence may range from 1\% (Amaral, 2014) to 6\% (Zimermann et al., 2012). However, as the etiology of DCM has not been elucidated yet, and its effects on the systemic health of broilers are still unknown.

Laboratory tests are used for the diagnosis and assessment of the general health of an animal, but the association between physiological aspects and clinical and laboratory parameters of poultry is not fully elucidated (Schmidt et al., 2007). Blood parameters may be influenced by the bird's nutritional and reproductive status, sex, age, habitat, season of the year, trauma, rearing system, and environmental stress (Campbell, 2004; Thrall, 2004). Blood parameters are used to monitor an animal's general health status, its capacity to fight infectious agents (Voigt, 2003), its physiological status, its reactions to the exposure to different environmental factors (Schmidt et al., 2007), and to diagnose diseases (Noriega, 2000) by evaluating quantitative and qualitative changes in red and white blood cell components (Fudge \& Joseph, 2000).

The measurement of the activity of the enzyme aspartate aminotransferase (AST) in the blood provides a non-specific marker of hepatocellular injury, and should be measured along with the activity of creatine kinase $(C K)$ to differentiate liver from muscle injuries. Creatine kinase is a muscle-specific enzyme, and its measurement aids the assessment of muscle function in poultry (Lumeij, 1997). Increased CK activityis an indication of muscle lesion, lead poisoning, septicemias, or myopathies caused by vitamin $\mathrm{E}$ and selenium deficiencies. A dramatic increase in serum CK activity is associated with capture myopathy or shock disease, in which AST concentrations do not significantly increase (Campbell, 2004). However, muscle and liver lesions may occur simultaneously, and may be triggered by the same or by different pathological processes (Hochleithner, 1994). Moreover, only marked increases in CK serum activity are clinically meaningful, becauses light muscle lesions, intramuscular injections, moderate transient muscle ischemia, seizures, and muscle jerks also increase CK activity (Lumeij, 1997).

The objective of this study was to determine the effects of DCM on the systemic health of broilers.

\section{MATERIALSAND METHODS}

\section{Location, experimental period, birds, and management}

The experiment was carried out between July and August 2013with broilers reared on three broiler farms and slaughtered at the same processing plant belonging to broiler company in the state of Rio Grande do Sul, Brazil. Male Cobb broilers were obtained from the same hatchery and were submitted to the same vaccination program. Approximately 12,000 broilers were housed on each farm in conventional houses with open sides protected with wire mesh and plastic curtains, and 10-cm deep wood-shavings litter. Environmental temperature was maintained between $24^{\circ} \mathrm{C}$ and $28^{\circ} \mathrm{C}$. Birds on the three farms were fed ad libitum the same feed, containing equal nutrient and energy levels. Birds were reared from one to 42 days of age.

\section{Blood sampling}

Sample size calculation for blood collection took into consideration that DCM lesions can only be observed during postmortem examination and its incidence is around $1 \%$ in winter, especially in heavier broilers. In total, 800 broilers with 42 days of age were selected on the three farms and identified with a numbered tag: 300 broilers with $2.79 \mathrm{~kg}$ average body weight (Farm 1), 200 broilers with $2.76 \mathrm{~kg}$ average body weight (Farm 2), and300 broilers with $2.90 \mathrm{~kg}$ average body weight (Farm 3). Blood was collected before feed withdrawal and transport to the processing plant. A3$\mathrm{mL}$ sample was collected from the ulnar vein of each broiler using a $20 \times 22$ needle; $1.5 \mathrm{~mL}$ was placed in heparinized tubes and $1.5 \mathrm{~mL}$ in tubes containing sodium fluoride (NaF). Blood samples were kept under refrigeration and submitted to the Clinical Analysis Laboratory of Passo Fundo University (UPF), state of Rio Grande do Sul. After blood collection, broilers were caught, and transported to the processing plant.

\section{Collection of data and tissue samples from broilers with and without DCM at the slaughterhouse.}

Upon arrival at the processing plant, birds were stunned, bled, scalded, plucked. Carcasses were examined after evisceration by trained employees.

During the postmortem examination, 28 carcasses with DCM-compatible lesions were identified, being13 from Farm 1and 15 from Farm 3.An equal number of carcasses with no DCM lesions (control group) was selected from farm 1 and 3, and all 56 carcasses from each farm were refrigerated until carcass collection 
Amaral PC, Zimermann C, Santos LR, Noro M, Prá MD, Pilotto F, Rodrigues LB, Dickel EL
Evaluation of Physiological Parameters of Broilers

with Dorsal Cranial Myopathy was completed. No DCM-compatible lesions were detected in carcasses from Farm 2.

The $\mathrm{pH}$ of the pectoralis major muscle of the collected carcasses was measured was measured shortly after slaughter and inspection, immediately after chilling (baseline $\mathrm{pH}$ ), and 24 hours after refrigeration at $0 \pm 2$ ${ }^{\circ} \mathrm{C}$ (ultimate $\mathrm{pH}$ ), according to Bendall (1973), using a buffered sodium iodo acetate solution $(5 \mathrm{mM} / \mathrm{KCl}$ $150 \mathrm{mM}$ ) to inhibit glycolysis. Sample $\mathrm{pH}$ was readusing a pH meter (Sentron, model 1001) coupled to a probe (Sentron, LanceFET, model 1074001), whose fine tip was inserted directly into the muscles. Samples of the ALD muscle, heart, liver, gizzard, pancreas, kidneys, and lungs were collected during the late rigor mortis period. Tissue samples were fixed in $10 \%$ buffered formalin, dehydrated, embedded in paraffin, and stained with hematoxylin-eosin (HE), as proposed by Luna (1968), at the Laboratory of Avian Pathology (Canoas, RS).

\section{Blood analyses}

The blood in the NaF tubes was centrifuged at $800 \mathrm{xg}$, and the serum was placed in $1.5-\mathrm{mL}$ microtubes, and frozen at $-20{ }^{\circ} \mathrm{C}$ for determination of lactate (Bioclin, Brazil) and glucose (GOD-PAP; In Vitro, Brazil) serum levels. The blood in the heparinized samples was used for the determination of hematocrit (capillary tube), hemoglobin (cyanmethemoglobin, Labquest, Brazil) levels, and red blood cell, white blood cell and thrombocyte counts (Noro \& Wittwer, 2012). Leukocyte differential count was performed in smears dyed with Diff-Quik stain and analyzed under a microscope (1.000 x; Olympus 21CA). The remainder of heparinized blood samples were centrifuged at $800 \mathrm{xg}$, and the plasma was stored in $1.5-\mathrm{mL}$ microtubes, frozen at- $20^{\circ} \mathrm{C}$ for later determination of aspartate aminotransferase (AST; Bioclin, Brazil) and creatine kinase (CK, Bioclin, Brazil) activities, and serum concentrations of albumin (BCG, Labtest, Brazil), total protein (Biureto, Laborlab, Brazil) and cholesterol (CHOD, In vitro, Brazil). Biochemical analyses were performed in a semi-automatic analyzer (Mindray BA-88), with a coefficient of variation lower than 5\%. Globulin serum level was determined by subtracting albumin level from total protein level, and used to calculate albumin to globulin ratio (A:G ratio). The results obtained in the hematological and biochemical analyses were compared between the groups presenting DCM lesions or not.

\section{Statistical analysis}

Data were analyzed for normality (Shapiro-Wilk test) and homoscedasticity (Levene test), and then submitted to two-way analysis of variance. The following model was applied: $Y_{i j}=\mu+G_{i}+I_{j}+G_{i j}+\varepsilon_{i j}$, where: $Y_{i j}=$ calculated effect, $\mu=$ mean, $G_{i}=$ effect of the $i^{\text {th }}$ group, $\mathrm{I}_{\mathrm{j}}=$ effect of the $\mathrm{j}^{\text {th }}$ farm; $\mathrm{Gl}_{\mathrm{ij}}=$ interaction between group and farm, and $\varepsilon_{i j}=$ residual error. Means were compared by Tukey's test. Histological results were compared by Student's t-test. Statistical analyses were performed using IBM SPSS 19.0, with the significance level set at $95 \%$.

\section{RESULTS AND DISCUSSION}

Blood biochemical parameters were not significantly different between broilers with DCM lesions or not, except for AST and CK, which levels were higher in the DCM group than in the control group $(p<0.05$; Table 1). These results are consistent with the findings of Kuttappan et al. (2013), who verified higher AST and CK activities in broiler carcasses with white striping lesions compared with healthy carcasses. However, those authors reported higher average AST and CK levels, of 1,066 U/L and 123,973 U/L, respectively, in broilers with severe white striping lesions relative to those determined in the present experiment in carcasses presenting DCM lesions. Zimermann (2008) observed histologic lesions, such as degeneration, necrosis, and lympho-histiocytic infiltrate, in normal anterior latissimus dorsi muscle and in other grossly normal muscle groups of broilers; however, the authors did not analyze CK and AST levels. MacRae et al. (2006) reported levels of $955 \mathrm{IU} / \mathrm{L}$ for CK and $35.1 \mathrm{IU} / \mathrm{L}$ for AST in broilers with skeletal muscle fiber growth and growth associated myopathies. In addition to the increase in enzyme activities, those authors reported microscopic lesions, such as necrosis and basophilia, in the pectoris major and biceps muscles of 5-weekold broilers with myopathies. However, in the present study, except for the ALD, no other muscles were macroscopically or microscopically evaluated, and therefore, no comparisons with the study of MacRae et al. (2006) can be made.

Table 1 - Means and standard deviation of serum biochemical parameters for broilers with and without DCM.

\begin{tabular}{lccc}
\hline Parameter & DCM group & Control group & p value \\
\hline AST (IU/L) & $409 \pm 161$ & $320 \pm 94$ & 0.0134 \\
CK (IU/L) & $54.091 \pm 38.425$ & $35.203 \pm 28.613$ & 0.0364 \\
Albumin (g/L) & $22.8 \pm 0.16$ & $22.11 \pm 0.18$ & 0.0844 \\
Globulin (g/L) & $12.9 \pm 0.33$ & $14.8 \pm 0.39$ & 0.0268 \\
Albumin:Globulin & $1.91 \pm 0.73$ & $1.60 \pm 0.60$ & 0.0401 \\
Cholesterol (mg/dL) & $153 \pm 11.9$ & $149 \pm 15.2$ & 0.2539 \\
Glucose (mg/dL) & $241 \pm 30.1$ & $242 \pm 30.5$ & 0.9069 \\
Lactate $(\mathrm{mg} / \mathrm{dL})$ & $30.6 \pm 7.4$ & $31.3 \pm 8.9$ & 0.6831 \\
\hline
\end{tabular}


Amaral PC, Zimermann C, Santos LR, Noro M, Prá MD, Pilotto F, Rodrigues LB, Dickel EL
Evaluation of Physiological Parameters of Broilers

with Dorsal Cranial Myopathy
The histological analyses of the ALD muscle of broilers presenting DCM confirmed the presence of fibers with moderate to severe floccular necrosis, hyalinization, and moderate to severe coagulative necrosis of muscle fibers, with no adipocyte changes in the affected fibers, mild to moderate multifocal mononuclear infiltration, and diffuse edema. The liver presented moderate to diffuse hepatocyte vacuolization, cholangitis, cholestasis, and bile duct hyperplasia. These findings are consistent with those of Zimermann (2008), who detected similar histological muscle lesions as well as moderate bile duct proliferation and hepatocyte vacuolization in broiler carcasses presenting DCM. These liver findings, along with the muscle lesions mentioned earlier, explain the increase in AST activity. In the lung, there was moderate multifocal interstitial bronchopneumonia. The samples obtained from the muscles and viscera of carcasses with no DCM did not show any important histological lesions.

No differences in erythrocyte and thrombocyte counts, hematocrit values, or hemoglobin levels were detected between DCM and control carcasses ( $p>0.05$, Table 2). Total erythrocyte counts allow diagnosing anemia or hemoconcentration (Noriega, 2000), and its levels vary across bird species, age, sex, and are influenced by hormones and environmental factors (Campbell, 2004).

Table 2 - Hematological parameters of broilers with DCM and without DCM (means and standard deviation) and reference values for Gallus gallus domesticus.

\begin{tabular}{lccc}
\hline Parameter & DCM group & Control group & p value \\
\hline Erythrocytes $(\times 10 \% / \mu \mathrm{L})$ & $2.25 \pm 0.34$ & $2.39 \pm 0.34$ & 0.1561 \\
Hematocrit $(\%)$ & $30.9 \pm 2.69$ & $31.0 \pm 3.02$ & 0.9206 \\
Hemoglobin $(\mathrm{g} / \mathrm{L})$ & $100 \pm 22.2$ & $96.5 \pm 8.69$ & 0.4386 \\
Thrombocytes $(/ \mu \mathrm{L})$ & $12,924 \pm 5,798$ & $12,337 \pm 5,594$ & 0.6046 \\
Leukocytes $(/ \mathrm{L})$ & $8,041 \pm 4,100$ & $7,784 \pm 4,027$ & 0.7574 \\
Heterophils $(/ \mu \mathrm{L})$ & $3,326 \pm 2,189$ & $2,644 \pm 2,029$ & 0.2345 \\
Lymphocytes $(/ \mu \mathrm{L})$ & $3,887 \pm 2,879$ & $4,431 \pm 2,397$ & 0.4619 \\
Monocytes $(/ \mu \mathrm{L})$ & $503 \pm 574$ & $608 \pm 538$ & 0.5340 \\
\hline Eosinophils $(/ \mu \mathrm{L})$ & $153 \pm 228$ & $173 \pm 244$ & 0.6863 \\
\hline
\end{tabular}

Total differential and absolute leukocyte counts were statistically similar between DCM and control broiler carcasses ( $p>0.05$, Table2). Kuttappan et al. (2013) did not identify any hematological differences between broilers with and without white-striping lesions either. Leukocyte counts are associated with the inflammatory response (Kokosharov, 1998), and differential leucocyte counts allows identifying the viral or bacterial nature of an infection and the general health status of an animal (Noriega, 2000; Campbell, 2004). In general, white blood cell count in peripheral blood increases in of stress situations and inflammatory conditions due to generalized or localized infections, trauma, toxicity, neoplasms. However, in poultry, total leukocyte and absolute lymphocyte counts maybe abnormal owing to the fact that activated thrombocytes may be mistaken for lymphocytes, resulting in an overestimation of lymphocyte counts. Therefore, total and differential leukocyte counts in birds, fishes, reptiles, and amphibians must be performed by an experienced technician (Noro \& Wittwer, 2012).

The obtained glucose and cholesterol levels are consistent with the reference values proposed by Lumeij (1997) and Campbell (2004) values for clinicallyhealthy broilers, and were not different between the evaluated groups ( $p>0.05$; Table 1). Hyperglycemia is associated with acute stress, and blood glucose levels increases due to pre-slaughter fasting (Puvadolpirod \& Thaxton, 2000). Also, no significant differences in the serum levels of lactate were determined between the DCM and the control groups ( $p>0.05$; Table 2). Lactate is an end product of anaerobic glycolysis and it is used as stress indicator in animals at the time of slaughter (Bertolini et al., 2006); however, this does not apply to the present study because blood samples were collected prior to fasting.

The DCM and the control groups presented average albumin:globulin ratios of 1.91 and 1.60, respectively. These ratios are higher than that reported by Lumeij (1997), of 0.8 for broilers. Although globulin values and albumin:globulin ratios were different between the MDC and control groups, no differences in total protein values were observed. According to Lumeij (1997), in both chronic and acute inflammatory processes, total plasma protein levels increase due to an increase in globulin levels and an occasional decrease in albumin levels, resulting in reduced albumin/globulin ratios. Differently from Lumeij (1997), both groups evaluated in the present study presented increased globulin levels, but changes in total protein levels.

No $\mathrm{pH}$ differences between MDC and control carcasses were detected in hot or chilled carcasses. However, after refrigeration, the $\mathrm{pH}$ value of 5.9 measured in carcasses from farm 1 with MDC lesions was significantly different of the $\mathrm{pH}$ of 5.7 obtained in the control carcasses ( $p<0.05$; Table 3$)$. In addition, no gross meat quality changes were detected in among the groups (data not shown). Chicken breast meat $\mathrm{pH}$ is5.7 to 5.9, on average (Mendes, 2001), and normal $\mathrm{pH}$ values, at the end of the postmortem examination, should range between 5.60 and 5.86 (Sams \& Mills, 1993). 
Amaral PC, Zimermann C, Santos LR, Noro M, Prá MD, Pilotto F, Rodrigues LB, Dickel EL

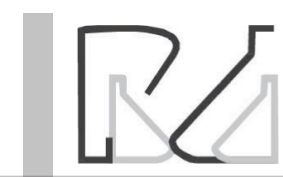

Evaluation of Physiological Parameters of Broilers

with Dorsal Cranial Myopathy
Table 3 - Means and standard deviation of pectoralis major muscle $\mathrm{pH}$ in broilers from the DCM and control groups.

\begin{tabular}{lccc}
\hline $\mathrm{pH}$ & DCM group & Control group & $\mathrm{p}$ value \\
\hline Shortly after slaughter & $6.37 \pm 0.12$ & $6.37 \pm 0.20$ & 0.9336 \\
After chilling (baseline $\mathrm{pH})$ & $6.15 \pm 0.12$ & $6.11 \pm 0.10$ & 0.1493 \\
$\begin{array}{l}\text { After refrigeration }\left(0 \pm 2{ }^{\circ} \mathrm{C},\right. \\
\text { final } \mathrm{pH})\end{array}$ & $5.88 \pm 0.16$ & $5.82 \pm 0.14$ & 0.0376 \\
\hline
\end{tabular}

The DCM group present significantly higher $(p<0.05)$ serum activities of AST (409 U/L) and CK (54.091 U/L) than the control group $(320 \mathrm{U} / \mathrm{L}$ and $35.203 \mathrm{U} / \mathrm{L}$ for AST and CK, respectively), which, together with the histological findings in the ALD muscle, show that the presence of DCM alone may increase the levels of enzyme markers of muscle damage.

The results of the present study showed that the AST and CK serum activities both in the DCM and control groups were abnormal compared with the average value $209 \mathrm{U} / \mathrm{L}$ determined in clinically healthy 42-day-old broilers by Borsa et al. (2006). In addition, the obtained AST and CK values of both evaluated groups were higher than those reported by Dickel (1992), 222 U/L for broilers with ascites, and those of Fernandez et al. (1994), of 198-225 U/L in layer hens fed a diet contaminated with aflatoxin.

The CK activity in the DCM carcasses determined in the present study was higher than those obtained by Lumeij (1997), who describes 0-350 U/L in clinically healthy broilers, as well as those reported by Dickel (1992), of $340 \mathrm{U} / \mathrm{L}$ in broilers with ascites. Bridi \& Silva (2012) determined CK values of $18.962 \mathrm{U} / \mathrm{L}$ and 17.705 $\mathrm{U} / \mathrm{L}$ in broilers slaughtered by Halal and conventional methods, respectively.

It should be noted, however, that healthy broilers (control group) may present lesions in other muscle groups, which may not be grossly detectable. As the other evaluated hematological and biochemical parameters, as well as the $\mathrm{pH}$ of pectoralis major muscle were not significantly different from the reference values or between the DCM and the control groups, it may be inferred that broilers presenting or not DCM are physiologically similar, except for the ALD muscle lesion.

\section{CONCLUSION}

Despite the observed higher muscle enzyme activities, broilers presenting dorsal-cranial myopathy did not show any abnormal hematological, biochemical or muscle $\mathrm{pH}$ values, indicating that the presence of this lesion does not affect their overall health status, and therefore, any health risks for consumers.

\section{REFERENCES}

Amaral PC. Indicadores de processo inflamatório sistêmico e de lesão muscular de frangos de corteacometidos pela miopatia dorsal cranial [dissertation]. Passo Fundo (RS): Universidade de Passo Fundo; 2014.

Bertoloni W, Silveira ETF, Ludtke CB, Andrade JC. Avaliação de diferentes híbridos suínos submetidos à insensibilização elétrica e gasosa (CO2). Parte 1 - mensuração de indicadores sanguíneos de estresse. Ciência e Tecnologia de Alimentos 2006;26:564-570

Borsa A, Kohayagawa A, Boretti L, Saito ME, Kuibida K. Níveis séricos de enzimas de função hepática em frangos de corte de criação industrial clinicamente saudáveis. Arquivo Brasileiro de Medicina Veterinária e Zootecnia 2006;(58):675-677

Brasil. Ministério da Agricultura, Abastecimento e Pecuária. Miopatia Dorsal Cranial (MDC). Aos SIFs de aves do RS [MVE n. 30/2010/SICAO/SIPOA/ DDA/SFA-RS]. Porto Alegre; 201.

Bridi AM, Silva CA. Indicadores de estresse e qualidade da carne em frangos abatidos pelo método "Halal". Semina: Ciências Agrárias 2012;(33):2451-2460

Campbell TW. Clinical chemistry of birds. In:Thrall MA. Veterinary hematology and clinical chemistry.Lippincott: Williams and Wilkins; 2004. p.479-492.

Dickel LE. Contribuição para julgamento sanitário de carcaças de frango acometidas de síndrome ascítica [dissertation]. Rio de Janeiro (RJ): Universidade Federal Fluminense; 1992

Doneley B. Avian medicine and surgery in practice: companion and aviary birds. London: Manson Publishing; 2010.

Fernandez A, Verde M, Gascon J, Ramos J, Gomez D, Luco F, et al. Variations of clinical biochemical parameters of laying hens and broiler chickens fed aflatoxin-containing feed. Avian Pathology 1994;(23):37-47.

Fudge AM, Joseph V. Avian complete blood count. In: Fudge AM. Laboratory medicine: avian and exotic pets. Philadelphia: W.B. Saunders; 2000. p.19-27.

Hochleithner M.Biochemistries. In: Ritchie BW, Harrison GJ, Harrison LR. Avian medicine: principles and application. Lake Worth: Wingers Publishing; 1994.p.176-98.

Kokosharov T. Changes in the white blood cells and specific phagocytosis in chicken with experimental acute fowl typhoid. Veterinary Archives 1998;(68):33-38.

Kuttappan VA, Huff GR, Huff WE, Hargis BM, Apple JK, Coon C, et al. Comparison of hematologic and serologic profiles of broiler birds with normal and severe degrees of white striping in breast fillets. Poultry Science2013;92(2):339-345.

Lumeij JT. Avian clinical biochemistry. In: Kaneko JJ, Harvey JW, Bruss ML. Clinical biochemistry of domestic animals. 5thed.San Diego: Academic Press; 1997. p.857-883.

LunaLG. Manual of histologic staining methods of the armed forces institute of pathology. 13thed. New York: McGraw-Hill;1968.

MacRae VE, Mahon M, Gilpin S, Sandercock DA, Mitchell MA. Skeletal muscle fibre growth and growth associated myopathy in the domestic chicken (Gallus domesticus). British Poultry Science 2006;(4):246-272.

Mendes AA. Jejum pré-abate em frangos de corte. Revista Brasileira de Ciência Avícola 2001;(3):199-209.

Noriega MLVC. Apuntes de hematología aviar: material didático para curso de hematologia aviária. México: Departamento de Produccíon Animal, Universidad Nacional Autónoma de México;2000. 
Amaral PC, Zimermann C, Santos LR, Noro M, Prá MD, Pilotto F, Rodrigues LB, Dickel EL

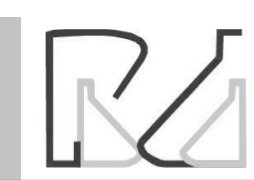

Evaluation of Physiological Parameters of Broilers with Dorsal Cranial Myopathy
Noro M, Wittwer F. Hematología de Salmonídeos. Valdivia: Master Print; 2012.

Olivo R, Shimokomaki M. Carnes no caminho da pesquisa. 2nd ed. Cocal do Sul: Imprint; 2002.

Puvadolpirov S, Thaxton JP. Model of physiological stress in chickens 1. Response parameters. Poultry Science 2000;79:363-369.

Sams AR, Mills KA. The effect of withdrawal duration on the responsiveness of broiler pectoralis to rigor mortis acceleration. Poultry Science 1993;(72):1789-1796.

Schmidt EMS, Locatelli-Dittrich Santin E, Paulillo AC. Patologia clínica em aves de produção: uma ferramenta para monitorar a sanidade avícola - revisão. Archives of Veterinary Science2007;(12):9-20.
Thrall MA. Veterinary hematology and clinical chemistry. Lippincott: Williams and Wilkins; 2004

Voigt GL, Conceptos y técnicas hematológicas para técnicos veterinários. Zaragoza: Editorial Acribia; 2003.

Zimermann FC, Fallavena LCB, Salle CTP, Moraes HL, Soncini RA, Barreta $\mathrm{MH}$, et al. Downgrading of heavy broiler chicken carcasses due to myodegeneration of the anterior latissimus dorsi: pathologic and epidemiologic studies. Avian Diseases 2012;(56):418-421.

Zimermann FC. Miopatia dorsal cranial em frangos de corte: caracterização anátomo-patológica, colheita e análise de dados[dissertation].Porto Alegre (RS): Universidade Federal do Rio Grande do Sul; 2008. 